\title{
Hazard Analysis of Listeria monocytogenes Contaminations in Processing of Salted Roe from Walleye Pollock (Theragra chalcogramma) in Hokkaido, Japan
}

\author{
Koichi TAKESHI ${ }^{1) *}$, Masahiko KITAGAWA ${ }^{2)}$, Mutsuyo KADOHIRA ${ }^{3)}$, Shizunobu IGIMI ${ }^{4)}$ and Sou-Ichi MAKINO ${ }^{5)}$ \\ ${ }^{1)}$ Department of Applied Veterinary Science and Public Health, Obihiro University of Agriculture and Veterinary Medicine, 2-11 Inada- \\ cho, Obihiro, Hokkaido 080-8555, ') Division of Marine Products Utilization, Hokkaido Kushiro Fisheries Experiment Station, 4-25 \\ Hamanaka-cho, Kushiro, Hokkaido 085-0027, ${ }^{3)}$ Department of Animal Science, Obihiro University of Agriculture and Veterinary \\ Medicine, 2-11 Inada-cho, Obihiro, Hokkaido 080-8555, ${ }^{4}$ Division of Biomedical Food Research, National Institute of Health Sciences, \\ 1-18-1 Kami-youga, Setagaya-ku, Tokyo 158-8501, and ${ }^{5}$ Laboratory of Food Microbiology and Immunology, Research Center for \\ Animal Hygiene and Food Safety, Obihiro University of Agriculture and Veterinary Medicine, 2-11 Inada-cho, Obihiro, Hokkaido 080- \\ 8555, Japan
}

(Received 4 July 2008/Accepted 9 August 2008)

ABSTRACT. Hazard analysis of Listeria monocytogenes contamination during processing of salted walleye pollock (Theragra chalcogramma) roe was performed for a seafood plant in Japan from December 2005 to February 2006. As a result, L. monocytogenes number was detected on the pallet used for transport of barrels in the salting process and one of the rollers of the roller conveyor, which rotates while in contact with the bottoms of the barrels, but was not detected in any raw materials, interim products or final products. Thus, we believe that the pallet contamination initially occurred because of insufficient washing, that it was passed on to the bottoms of the barrels and that it was then passed on the roller of the roller conveyor by cross-contamination. Therefore, it is possible that interim and final products may become contaminated by processing devices and machinery. In addition, we conducted an inoculation study designed at the $1 / 20$ actual factory scale using interim products with or without artificial color and seeded with L. monocytogenes to observe changes in its growth. In the inoculation study, multiplication of L. monocytogenes during the salting process was not confirmed in the samples with artificial color.

KEY WORDS: food hygiene Listeria monocytogenes, salted walleye pollock roe.

J. Vet. Med. Sci. 71(1): 87-91, 2009

L. monocytogenes is known to be the causative agent of listeriosis in humans and animals [6, 8]. Its clinical signs include influenza-like symptoms, headache and nausea, together with acute gastroenteritis-like symptoms, meningitis and bacteremia $[3,15,17]$. Neonates, pregnant women and immunocompromised patients have high likelifoods of developing symptoms $[4,14]$.

Listeriosis outbreaks resulting from contamination of milk, cheese, vegetables and meat have been reported worldwide $[5,9,16,18,20]$. In the U.S.A., approximately 2,500 people develop serious listeriosis, and 500 people die as a result of listeriosis each year [11]. This proportion is equivalent to approximately $10 \%$ of the total number of deaths due to food-borne infection. In Japan, there have been no reports of outbreaks documented so far, but a single case of food-borne listeriosis due to natural cheese in 2001 was reported for the first time in 2005 [10]. Since the level of food contamination in Japan is similar to that in Europe and the US [13], there is a high chance of food-borne listeriosis outbreaks in Japan in the near future. Salted walleye pollock (Theragra chalcogramma) roe is a common, raw, ready-to-eat seafood product in Japan, but the prevalence and rate of contamination for $L$ monocytogenes in food has

\footnotetext{
* Correspondence to: Takeshi, K., Department of Applied Veterinary Science and Public Health, Obihiro University of Agriculture and Veterinary Medicine, 2-11 Inada-cho, Obihiro, Hokkaido 080-8555, Japan.

e-mail: takeshi@obihiro.ac.jp
}

not been sufficiently investigated. The salting process is one of the most important steps during processing therefore, we performed a hazard analysis of L. monocytogenes contamination of walleye pollock roe during processing and conducted an inoculation study using interim products seeded with $L$. monocytogenes to observe changes in its growth in the salting process in order to investigate the cause of contamination in a seafood plant in Hokkaido, Japan.

The processing plant used frozen raw walleye pollock roe imported as raw material for production of a ready-to-eat product (Tara-ko). In the processing plant, the raw material was thawed, salted using a commercial tilting machine for 7 $\mathrm{hr}$ at $20^{\circ} \mathrm{C}$ and then washed, drained, formed, chilled, boxed and frozen as shown in Fig. 1. At the end of each day, a cleanup crew sanitized the equipment according to a company sanitation procedure based on the Current Good Manufacturing Practices of the U.S. Food and Drug Administration (FDA) [1].

A total of 80 samples were collected from the processing environment (surfaces and drains), machines and employees' gloves. During processing of Tara-ko, the above items were swabbed around a $10.0 \mathrm{~cm}$ by $10.0 \mathrm{~cm}$ area using sterile cotton plugs (Eiken-Kizai Co., Ltd., Tokyo, Japan) premoistened with sterile saline. Two plugs were used for each sample. Samples from the gloves of the handlers in each step of processing were taken by swabbing. At each step, $25-\mathrm{g}$ portions of semi-processed and final roe products and 


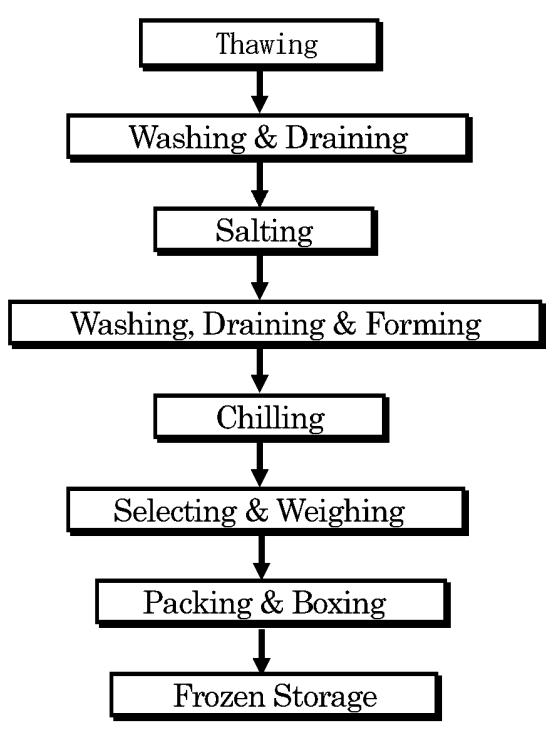

Fig. 1. Process for producing salted Tara-ko. The processing plant used frozen raw walleye pollock roe imported as raw material for production of a ready-to-eat product (Tara-ko). In the processing plant, the raw material was thawed, salted with a commercial tilting machine for $7 \mathrm{hr}$ at $20^{\circ} \mathrm{C}$, washed, drained, formed, chilled, boxed and then frozen. of salting solution were collected.

Examinations for L. monocytogenes and other Listeria spp. were carried out according to the ISO method 11290 part 2 [19]. Each sample was incubated in half-Fraser broth (primary Listeria enrichment broth; Oxoid, Hampshire, UK) at $30^{\circ} \mathrm{C}$ for $24 \mathrm{hr} ; 1-\mathrm{m} l$ portions of the culture were then transferred to Fraser broth (secondary Listeria enrichment broth; Oxoid) and incubated at $30^{\circ} \mathrm{C}$ for $24 \mathrm{hr}$. An aliquot of secondary enrichment culture from each sample was streaked with a sterile loop onto both Palcam agar (Merck, Darmstadt, Germany) and CHROMagar Listeria (CHROMagar Microbiology, Paris, France). Five suspected colonies isolated from each agar plate were streaked onto blood agar, and then the beta-hemolytic colonies were identified by the methods described in the Bacteriological Analytical Manual of the U. S. FDA [7]. Total aerobic bacteria and coliform bacteria were also enumerated. For these analyses, each sample from the processing plant was plated onto Standard Plate Count Agar (Oxoid) and CHROMagar ECC (CHROMagar Microbiology), respectively, and incubated at $35^{\circ} \mathrm{C}$ for 24 to $48 \mathrm{hr}$ before counting the numbers of colonies.

Sample $\mathrm{pH}$ was measured using a $\mathrm{pH}$ meter (F23, Horiba Seisakusho, Kyoto, Japan). The salt content and water activity of the samples were determined as follows. A $10 \mathrm{~g}$ sample was weighed, homogenized with $50 \mathrm{~m} l$ of distilled

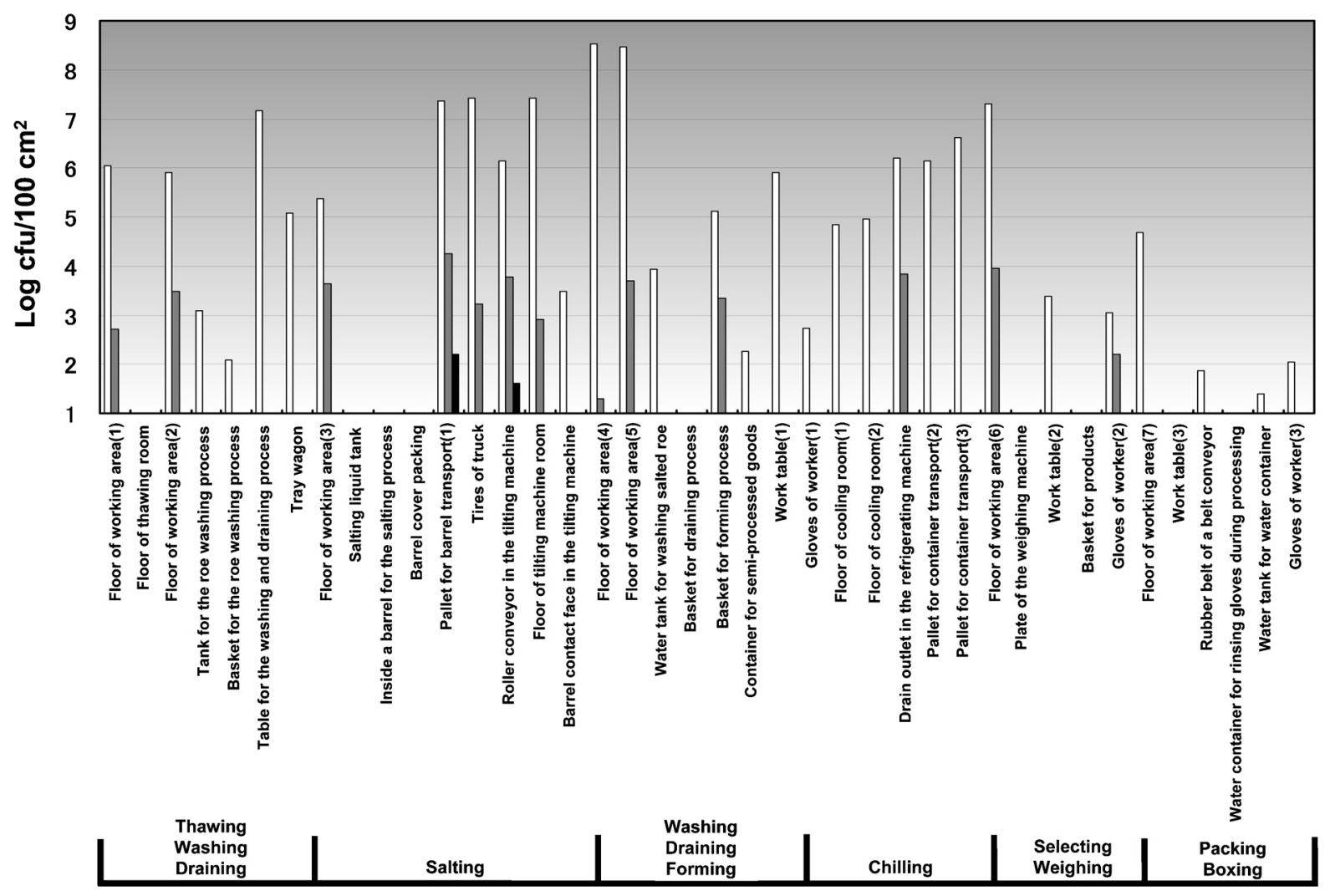

Fig. 2. Results of microbiological tests on samples collected from processing stages. $\square$ : Total aerobic bacteria. $\square$ : Coliform bacteria. I. monocytogenes. 
Table 1. Microbiological and physiological characteristics of raw material, interim products, salting solution and final products

\begin{tabular}{lcccccc}
\hline Samples tested & $\mathrm{pH}$ & $\begin{array}{c}\text { Salt content } \\
(\%)\end{array}$ & Aw & $\begin{array}{c}\text { Aerobic count } \\
(\mathrm{CFU} / \mathrm{g})\end{array}$ & $\begin{array}{c}\text { Coliform } \\
(\mathrm{CFU} / \mathrm{g})\end{array}$ & $\begin{array}{c}\text { Listeria spp. } \\
(/ 25 \mathrm{~g})\end{array}$ \\
\hline Thawed, washed and drained roe & 6.08 & 0.8 & 0.99 & 30 & Negative & Negative \\
Salting solution (before use) & 6.97 & Not determined & Not determined & 35 & Negative & $\begin{array}{c}\text { Negative } \\
\text { Salting solution (after use) }\end{array}$ \\
Roe after salting & 6.17 & Not determined & Not determined & $1.3 \times 10^{3}$ & Negative & Negative \\
Washed and drained roe & 6.19 & 5.3 & 0.94 & $4.9 \times 10^{2}$ & Negative & Negative \\
Chilled and stocked roe & 6.22 & 5.2 & 0.94 & $6.3 \times 10^{2}$ & Negative & Negative \\
Final products & 6.19 & 5.6 & 0.94 & $2.1 \times 10^{2}$ & Negative & Negative \\
\end{tabular}

Table 2. Changes of $\mathrm{pH}$ in raw roe, salted roe and during strage at different temperatures

\begin{tabular}{cccccc}
\hline \multirow{2}{*}{$\begin{array}{c}\text { Batch } \\
\text { Number }\end{array}$} & \multirow{2}{*}{$\begin{array}{c}\text { Temperature } \\
\left({ }^{\circ} \mathrm{C}\right)\end{array}$} & \multicolumn{3}{c}{ Samples tested } \\
\cline { 3 - 6 } & 4 & Raw roe & Salted roe & Incubation time 1* & Incubation time 2** \\
\hline 1 & 4 & ND & ND & 6.25 & 6.25 \\
2 & 4 & ND & ND & 6.31 & 6.31 \\
3 & 10 & ND & ND & 6.3 & 6.29 \\
4 & 10 & ND & ND & 6.31 & 6.25 \\
5 & 10 & ND & ND & 6.3 & 6.3 \\
6 & 20 & 6.6 & 6.24 & 6.26 & 6.27 \\
7 & 20 & 6.16 & 6.28 & 6.31 & 6.2 \\
8 & 20 & 6.06 & 6.26 & 6.29 & 6.25 \\
9 & & & & &
\end{tabular}

ND: Not determined.

* Samples incubated for $20 \mathrm{hr}$ and ** $40 \mathrm{hr}$ after salting process were finished.

water and then diluted to $100 \mathrm{~m} l$ for determination of salt content. A 5-m $l$ aliquot of this solution was titrated with 0.1 $\mathrm{N} \mathrm{AgNO}_{3}$, and the salt content was then calculated. For water activity, one gram of each sample in duplicate was placed into a pre-weighed aluminum foil plate $(30 \mathrm{~mm})$ that was then placed into a Conway water activity test apparatus (Sibata Scientific Technology Ltd., Tokyo, Japan) containing a saturated salt solution at a relative humidity of $75.8 \%$ to $100 \%$. The samples were incubated for $2 \mathrm{hr}$ at $25^{\circ} \mathrm{C}$ after sealing the unit with Vaseline. The samples were then weighed, and the water activities of the samples were calculated.

We conducted an inoculation study designed at $1 / 20$ of the actual factory scale using interim products seeded with L. monocytogenes in order to observe changes in growth directly in the walleye pollock roe. L. monocytogenes strain ATCC 7644 and smoked salmon isolated strain SS02 [10] were combined in this study to serve as an inoculum. Stock cultures were transferred to Tryptone Soya Broth (Oxoid) and incubated for $24 \mathrm{hr}$ at $30^{\circ} \mathrm{C}$ under aerobic conditions. After cultivation, the cells were concentrated by centrifugation, washed twice with phosphate-buffered saline $(0.1 \mathrm{M}$, $\mathrm{pH}$ 7.0) and then suspended in the same buffer. Suitable amounts of this working culture were dispersed into $50 \mathrm{~m} l$ of the buffer, and $1 \mathrm{~m} l$ portions from each cell suspension were used as inocula for survival studies of $L$. monocytogenes in interim Tara-ko products as described below.

The ovary membrans were aseptically removed from 18 $\mathrm{kg}$ of raw walleye pollock roe from the processing plant to prepare homogeneous starting inocular samples, and the roe was then divided into $18 \times 1-\mathrm{kg}$ batches along with the salting solution containing $10 \% \mathrm{NaCl}, \mathrm{NaNO}_{2}$ and a few kinds of seasonings provided by the plant. Half of these batches contained artificial color (Food Color Red 102 and Food Color Yellow 5, Hodogaya Chemical Co., Ltd., Kawasaki, Japan). Details about the contents, concentrations and application methods of the additives (except $\mathrm{NaCl}$ ) in the solution were unknown because they are proprietary information. After inoculation of these samples with L. monocytogenes, 9 batches were incubated at $20^{\circ} \mathrm{C}$ for $7 \mathrm{hr}$, divided again into three groups (three replicates each) according to incubation temperatures of $4^{\circ} \mathrm{C}, 10^{\circ} \mathrm{C}$ and $20^{\circ} \mathrm{C}$ and then incubated for $20 \mathrm{hr}$ and $40 \mathrm{hr}$ to monitor survival and growth. The colony forming units (CFU) were counted in duplicate on Palcam agar and CHROMagar Listeria plates after cultivation at $30^{\circ} \mathrm{C}$ for $48 \mathrm{hr}$. In addition, all samples were screened for total aerobic bacteria as well as coliform bacteria using Standard Plate Count Agar (Oxoid) and CHROMagar ECC (CHROMagar Microbiology), respectively.

The microbiological and physiological characteristics of the interim products in each processing step, of the salting solution (before and after being used) and of the final products are summarized in Table 1. Neither L. monocytogenes nor coliform bacteria was detected in any samples. Total bacterial counts were within normal limits. Figure 2 shows the microbiological test results for samples collected from the processing environment (surfaces and drains), machines and employees' gloves at each processing stage. L. monocytogenes was detected only on the pallet used for transport 
Table 3. Salt concentration and changes of water activity (Aw) in raw roe, salted roe and during storage at different temperature

\begin{tabular}{ccccccc}
\hline \multirow{2}{*}{$\begin{array}{c}\text { Batch } \\
\text { Number }\end{array}$} & $\begin{array}{c}\text { Temperature } \\
\left({ }^{\circ} \mathrm{C}\right)\end{array}$ & \multicolumn{5}{c}{ Salt content $(\%)$} \\
\cline { 3 - 6 } & Raw roe & Salted roe & Incubation time 1* & Incubation time 2** & \\
\hline 1 & 4 & ND & ND & 6.25 & 6.25 & 0.94 \\
2 & 4 & ND & ND & 6.31 & 6.31 & 0.94 \\
3 & 4 & ND & ND & 6.3 & 6.29 & 0.94 \\
4 & 10 & ND & ND & 6.25 & 6.25 & 0.94 \\
5 & 10 & ND & ND & 6.31 & 6.3 & 0.94 \\
6 & 10 & ND & ND & 6.3 & 6.27 & 0.94 \\
7 & 20 & 0.7 & 6.24 & 6.26 & 6.2 & 0.94 \\
8 & 20 & 0.7 & 6.28 & 6.31 & 6.26 & 0.94 \\
9 & 20 & 0.7 & 6.26 & 6.29 & 6.25 & 0.94 \\
\hline
\end{tabular}

ND: Not determined.

* Samples incubated for $20 \mathrm{hr}$ and **40 hr after salting process were finished.

*** Samples incubated for $40 \mathrm{hr}$ after salting process were used for measuring of Aw.

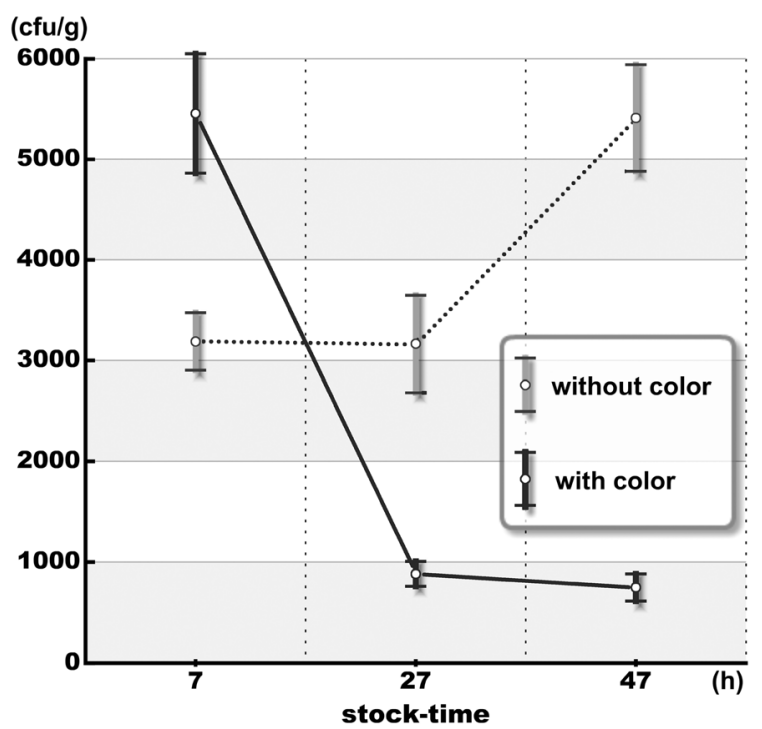

Fig. 3. L. monocytogenes counts (mean and $95 \% \mathrm{CI}$ ) with and without artificial color at each incubation time. An inoculation study was designed at $1 / 20$ of the actual factory scale using interim products seeded with $L$. monocytogenes to observe changes in growth directly in the walleye pollock roe. L. monocytogenes strain ATCC 7644 and smoked salmon isolate strain SS02 were combined in the present study to serve as an inoculum. - . - - : without artificial color. - : with artificial color.

and one of the rollers of the conveyor, which rotates while in contact with the bottoms of the barrels, in the salting process. Tables 2 and 3 showed the $\mathrm{pH}$ and salt concentrations of raw roe, respectively, before and after salting and chill storage at different temperatures. We found no significant change at any temperature. The difference in total aerobic bacterial counts was great: 30 to $35 \mathrm{CFU} / \mathrm{g}$ in raw-roe and $1.0 \times 10^{3} \mathrm{CFU} / \mathrm{g}$ after storage for $47 \mathrm{hr}$ following the salting procedure. No coliform bacteria were isolated from any samples (Table 1).

During these investigations, L. monocytogenes was detected on the pallet used to transport barrels in the salting process and on a conveyor roller, which rotates when in contact with the bottoms of the barrels, but not in any raw materials, interim products, or final products. We believe that contamination of the pallet first occurred because of insufficient washing, that it was passed on to the bottoms of the barrels and then, that it was potentially passed to the roller by cross-contamination, leading to diffusion to downstream processing sections by spatter of water from floors, hands, gloves and the ventilation system. Therefore, it is possible that interim and final products may be contaminated with $L$. monocytogenes indirectly via processing devices and machinery.

At the beginning of the inoculation study, the L. monocytogenes counts were $3.0 \times 10^{4} \mathrm{CFU} / \mathrm{g}$ for samples with and without artificial color (Fig. 3). Since there were no statistical differences in the averaged Listeria counts among the three batches at each temperature $\left(4^{\circ} \mathrm{C}, 10^{\circ} \mathrm{C}\right.$ and $\left.20^{\circ} \mathrm{C}\right)$, the nine Listeria counts were averaged separately (with and without artificial color) for the 7,27 and $47 \mathrm{hr}$ stock times and are shown in Fig. 3 [as means of the $95 \%$ Confidence Interval (CI)]. The average counts significantly decreased after $7 \mathrm{hr}$ with and without artificial color, but the counts of the samples with color were higher than those without color. However, the average counts of the samples without color were significantly higher at later time points (27 and $47 \mathrm{hr}$ ). At $47 \mathrm{hr}$, the counts differed by a factor of approximately 8 .

Interim products in the salting process had average values for $\mathrm{pH}$ (6.28), salt concentration (5.4\%) and Aw (0.941). The minimum Aw level for Listeria spp. growth requirement is 0.93 , but some Listeria strains can grow at Aw 0.90 [2], and during the salting process, Aw was close to the minimum Aw level. The Listeria counts of samples exposed to this salting solution first decreased and then increased after $47 \mathrm{hr}$ in samples without artificial color. This observation coincides with our finding that after the total aerobic bacterial numbers and coliform bacteria counts decreased, they again increased with longer incubation time in the processing plant samples (data not shown). In our inoculation study, multiplication of L. monocytogenes was not confirmed in the samples of roe during the salting process with 
and without artificial color. However, artificial color seems to have some kind of bacteriostatic effect as a chelating compound because the L. monocytogenes counts became much lower in the artificially colored samples over time. It is generally known that current artificial colors do not have a very strong effect on bacterial growth [12]; therefore, our conclusion is that the inhibition of $L$. monocytogenes growth was caused by the mutual influences of addition of artificial color and a low Aw.

Salted walleye pollock roe is a raw, ready-to-eat seafood product that the Japanese commonly consume, but it is sporadically contaminated with $L$. monocytogenes. As multiplication of $L$. monocytogenes during the salting process was not confirmed in the present inoculation study, we recommended that more exhaustive sterilization, washing and routine bacteriological examinations be performed for production lines in plants, that shorter shelf-lives be used for these products and that they should be stored more often below $5^{\circ} \mathrm{C}$ in the retail setting in order to avoid the occurrence of food-borne listeriosis due to contaminated salted walleye pollock roe.

\section{REFERENCES}

1. Anonymous. 2000. Current good manufacturing practice in manufacturing, packing, or holding human food. Code of Federal Regulations part 110, U. S. Government Printing Office, Washington, DC.

2. Anonymous. 2001. APPENDIX 4 Bacterial Patogen Growth and Inactivation. Fish \& FIisheries Products Hazards \& Controls Guides: Third Edition, U. S. Food \& Drug Administration, Center for Food Safety \& Applied Nutrition, Washington, DC.

3. Dalton, C. B., Austin, C. C., Sobel, J., Hayes, P. S., Bibb, W. F., Graves, L. M., Swaminathan, B., Proctor, M. E. and Griffen, P. M. 1997. An outbreak of gastroenteritis and fever due to Listeria monocytogenes in milk. New Engl. J. Med. 336: $100-105$.

4. Farber, J. M. and Peterkin, P. 1991. Listeria monocytogenes, a food-borne pathogen. Microbiol. Rev. 55: 476-511.

5. Fleming, D. W., Cochi, K. L., MacDonald, J., Brondum, P. S., Hayes, B. D., Plikaytis, M. B., Holmes, A. A., Broome, C. V. and Reingold, A. L. 1985. Pasteurized milk as a vehicle of infection in an outbreak of listeriosis. New Engl. J. Med. 312: 404-407.

6. Gray, M. L. and Killinger, A. H. 1966. Listeria monocytogenes and listeric infections. Bacteriol. Rev. 30: 309-382.

7. Hitchins, A. D. 2003. Chapter 10 Detection and enumeration of Listeria monocytogenes in foods. Bacteriological Analytical Manual, U. S. Food \& Drug Administration, Center for Food Safety \& Applied Nutrition, Washington, DC.

8. Inoue, K., Yamada, K., Kokubo, Y., Takeda, Y. and Ogawa H. 200a. Isolation of the zoonosis in the domestic animals, the domestic fowls and the pet animals in Hiroshima prefecture. p. 8. Hiroshima-ken Hoken Kankyo Center Kenkyu. Research Report of Hiroshima prefectural Health and Environmental
Center, Hiroshima.

9. Linnan, M. J., Mascola, L., Lou, X. D., Goulet, V., May, S., Salminen, C., Hird, D. W., Yonekura, M. L., Hayes, P., Weaver, R. E., Audurier, A., Plikaytis, B. D., Fannin, S. L., Kleks, A. and Broome, C. V. 1988. Epidemic listeriosis associated with mexican-style cheese. New Engl. J. Med. 319: 823828.

10. Makino, S.-I., Kawamoto, K., Takeshi, K., Okada, Y., Yamasaki, M., Yamamoto, S. and Igimi, S. 2005. An outbreak of food-borne listeriosis due to cheese in Japan, during 2001. Int. J. Food Microbiol. 104: 189-196.

11. Mead, P. S., Slutsker, L., dietz, V., McCaig, L. F., Bresee, J. S., Shapiro, C., Griffin, P. M. and Tauxe, R. V. 1999. Foodrelated illuness and death in the United States. Emerg. Infect. Dis. 5: 607-625.

12. Nakamura, M., Sakamoto, M., Kawashima, T., Aizawa, S., Kida, K. and Funaoka, T. 1990. pp. 53-57. In: Processing of Salted Walleye Pollack Roe. Kitano Suisan-kakou Jiten (Cyclopedia of marine products processing in Hokkaido, Japan.), Kita-nihon Kaiyou Center Co., Sapporo.

13. Okutani, A., Okada Y., Yamamoto, S. and Igimi, S. 2004. Overview of Listeria monocytogenes contamination in Japan. Int. J. Food Microbiol. 93: 131-140.

14. Pinner, R. W., Schuchat, A., Swaminathan, B., Hayes, P. S., Deaver, K. A., Weaver, R. E., Plikaytis, B. D., Reeves, M., Broome, C. V. and Wenger, J. D. 1992. Role of foods in sporadic listeriosis: II. Microbiologic and epidemiologic investigation. The Listeria Study Group. J. Am. Med. Assoc. 267: 20462050.

15. Salamina, G., Dalle, Donne, E., Niccolini, A., Poda, G., Cesarni, D., Bucci, M., Fini, R., Maldini, M., Schuchat, A., Swaminathan, B., Bibb, W., Rocourt, J., Binkin, N. and Salmaso, S. 1996. A foodborne outbreak of gastroenteritis involving Listeria monocytogenes. Epidemiol. Infect. 117: 429-436.

16. Schlech, W. F., Lavigne, P. M., Bortolussi, R. A., Allen, A. C., Haldane, E. V., Wort, A. J., Hightower, A. W., Johnson, S. E., King, S. H., Nicholls, E. S. and Broome, C. V. 1983. Epidemic listeriosis-evidence for transmission by food. N. Engl. J. Med. 308: 203-206.

17. Schuchat, A., Robinson, K., Wenger, J. D., Harrison, L. H., Farley, M., Reingold, A. L., Lefkowitz, L. and Perkins, B. A. 1997. Bacterial meningitis in the United States in 1995. Active Surveillance Team. N. Engl. J. Med. 337: 970-976.

18. Schwartz, B., Hexter, D., Broome, C. V., Hightower A. W., Hirschhorn, R. B., Porter, J. D., Hayes, P. S., Bibb, W. F., Lorber, B. and Faris, D. G. 1989. Investigation of an outbreak of listeriosis: new hypothesis for the etiology of epidemic Listeria monocytogenes infections. J. Infect. Dis. 159: 680-685.

19. Scotter, S. L., Langton, S., Lombard, B., Schulten, S., Nagelkerke, N., In't Veld, P. H., Rollier, P. and Lahellec, C. 2001. Validation of ISO method 11290 part 1-Detection of Listeria monocytogenes in foods. Int. J. Food Microbiol. 64: 295-306.

20. Tham, W., Ericsson, H., Loncarevic, S., Unnerstad, H. and Danielssontham, M. L. 2000. Lessons from an outbreak of listeriosis related to vacuum-packed graved and cold-smoked fish. Int. J. Food Microbiol. 62: 173-175. 